\title{
INTERCROPPING EFFECT ON SORGHUM YIELD UNDER SAHEL ZONE CLIMATE CONDITION OF MALI: CASE STUDY OF CINZANA
}

\author{
${ }^{1,2}$ Assitan DAOU, ${ }^{1}$ Bocar AHAMADOUN, ${ }^{2}$ Aly BOUBACAR, \\ ${ }^{2}$ Alfoussseyni MAÏGA, ${ }^{2}$ Abdoulaye DIALLO \\ ${ }^{1}$ West African Science Service Center on Climate Change and Agriculture (WASCAL CC \& ALU), \\ Institut Polytechnique Rurale de Formation et Recherche Appliquée, Bamako, Mali. \\ ${ }^{2}$ Programme Sorgho, Institut d'Economie Rurale (IER) \\ DOI: https://doi.org/10.51193/IJAER.2021.7613
}

Received: 10 Dec. 2021 / Accepted: 20 Dec. 2021 / Published: 01 Jan. 2022

\begin{abstract}
Cereal-leguminous cropping systems are part of logic of sustainable intensification. However, in the Sahelian zones of Mali, the yields of these associations are generally low due to the inadequate practice of this system. To minimize the negative effects of climate variability, it is important to assess the effects of the association on soil characteristics and on sorghum yield.

In this purpose, a precipitation data from 59 years were analyzed and two experiments were carried out in the 2017 and 2018 season on two sowing dates. Analysis of the precipitation data indicates that the average rainfall in the study area is $700.30 \mathrm{~mm}$ and the rainy season is June to October.

The results of the experiment show that a slight variation in the diameter of the stem, the height of the plant and these are only significantly affected by the genotype. The highest grain yield (2193 and $1842 \mathrm{~kg} / \mathrm{ha}$ ) and biomass yield (4570 and 4637) were recorded with a row of Jacumbe sorghum alternated with 1 row of Korobalen cowpea (2Jac1Kor) in the two sowing dates. Stem diameter, plant height, LAI, number of leaves, grain and biomass yield were not affected by the cropping system during the 2018 rainy season. The best cereal yield was obtained with 1 Kor2Tiand in the second sowing (1377 kg / ha) and the best biomass yield (2378 kg / ha) with 2 Kor1Jac in the first sowing.

LER values greater than 1.0 were obtained for all cross-crop treatments. The result confirms that a higher total yield can be obtained from sorghum-legume intercropping than sole sorghum cropping. This technology therefore makes it possible to produce more on less sown area.
\end{abstract}


International Journal of Agriculture and Environmental Research

ISSN: 2455-6939

Volume: 07, Issue: 06 "November-December 2021"

The study allowed us to understand that the season (year) strongly affected the yield of sorghum grains and biomass. This can be explained by the reduction in the amount of precipitation (725.1mm) during the rainy season 2018 compared to $2017(882.7 \mathrm{~mm})$.

Keywords: Climate Variability, Sorghum, Farm size, Small-scale Farmers.

\section{INTRODUCTION}

Adverse effects of climate change may alter the composition of farming systems. Specifically, a reduction in length of the growing season and increases in the frequency of failed seasons. Increasing temperatures and decreasing precipitation will affect agriculture and food security. Change in rainfall patterns, rainfall variability and temperature are likely to increase the severity of periodic drought and extend dry seasons and thus decrease crop yield in several regions.

Agricultural production in the Sahel region is heavily dependent on rainfall for the production of sorghum, millet, and cotton and maize. Farmers experience low yields resulting in increasing uncertainty about being able to produce the food needed for their families (Breman and Sissoko, 1998; Drechsel et al., 2001).

Agriculture is the key livelihood in Mali, followed by livestock breeding and fishery, all of which largely depend on suitable temperatures and precipitation. Agriculture and related activities, which are strongly resource-dependent, make up 75-85\% of Mali's labour force and provide $42 \%$ of the GDP. This indicates the vulnerability of the Malian economy to climate extremes in general and climate change in particular.

Agriculture in Mali is very vulnerable to climate change. Rainfall remains uncertain for the future (Sultan and Janicot, 2003), while the increase in temperature is almost a certainty (Schwartz and Randall, 2003). This is a major challenge for agriculture which depends almost entirely on rainfall, as average temperatures would be close to highest values $\left(1\right.$ to $2,75{ }^{\circ} \mathrm{C}$ or more by 2030) (Oxfam, 2007) that could be harmful to the growth and development of crops. Crop production in Mali is essentially characterized by subsistence farming based on millet and sorghum in the Central and Northern region, and commercial agriculture dominated by growing cotton and rice in the southern regions and the centre. The yield of rice and cotton have seen a considerable increase (cotton $1 \mathrm{t} / \mathrm{ha}$ and rice $5 \mathrm{t} / \mathrm{ha}$ ), while those of rainfed food crops (sorghum $0.8 \mathrm{t} / \mathrm{ha}$ and millet, $0.7 \mathrm{t} / \mathrm{ha}$.) evolved slowly in the last 50 years, despite being the base of food for more than $80 \%$ of the population (DNS, 1995).

Negative impacts of climate change on crop productivity increase in severity as warming intensifies, emphasizes the importance of coping with global warming The IPCC's fifth Assessment Report (AR5) presents new evidence of climate change (IPCC, 2013) and adapting cropping systems to the likely climate change is essential. Several adaptation options which help 
International Journal of Agriculture and Environmental Research

ISSN: 2455-6939

Volume: 07, Issue: 06 "November-December 2021"

Malian farmers to cope with current climate variability could be considered (Traore, 2014). Farm production practices are in general: water management, fertilisation, crop land increases but also asset management/income as diversification of activities and migration (Chuku and Okoye, 2009). Changing the sowing date to the starting of the season is another common practice of farmers in the semi-arid regions (Muller et al., 2010). Studies for West Africa's crop simulation studies showed that sowing date and cultivar type adaptation can reduce the negative climate change impacts and increase crop yields (Tingem and Rivingto, 2009). The same authors showed a simulated $15 \%$ and $40 \%$ decrease in maize and sorghum yield respectively caused by climate change was converted to $32 \%$ and $18 \%$ increase respectively with the use of different variety with a longer crop growing period. Similarly, Butt et al. (2005) argued that by implementing adaptive responses such as the use of high-temperature-resistant crop varieties together with addressing soil fertility decline and economic gains could exceed losses caused by climate change in Mali.

\section{RESEARCH METHODOLOGY}

\section{Study area}

The study has been conducted at agricultural research station of Cinzana in Mali; a Sahelian zone (figure 1). These agro-ecological zones have more than $60 \%$ of the population engaged in agriculture and characterized by a single, relatively long rainy season from April to early July and ending between September and October. Key food staples include millet, sorghum, maize, rice, cowpea and groundnut produced predominantly under smallholder production systems. The agriculture sector is affected negatively by climate variability, including drought, flood, heat waves and other extreme weather events. Consequently, cropping systems are characterized by low production due to erratic rainfall, poor soil fertility and poor crop management.

Cinzana is a village and rural Community in the Region of Segou in the Segou Region of southern-central Mali. Etymologically, Cinzana is the distortion of "Zele and Zan" Zele being women and Zan her husband. The name was assigned to the village of Cinzana by the population coming from Séribougou village (Cinzana Community).

There is a research station situated $5 \mathrm{~km}$ from the Cinzana village. Research activities are performed at the Agricultural Research Station de Cinzana (CRRA). It is one of eight (8) major research stations of the Institute of Rural Economy (IER) and reports of the Regional Agricultural Research Centre (CRRA) Niono, one of six regional research centres of IER since its restructuring in 1992.

From a climate perspective, Cinzana Community is situated on latitude $13^{\circ} 15 \mathrm{~N}$ and on longitude $5^{\circ} 57 \mathrm{~W}$ which makes it a Sahelian zone type semi-arid area. The mean characteristic feature is 
the change of a long dry season from November to May and a rainy season from June to October. The range annual rainfall of the last ten years is 600 to $700 \mathrm{~mm}$. This amount is unevenly distributed over the period, is insufficient for the needs of cropping which largely justifies the successive years of crop failure. The average temperature ranges between $28{ }^{\circ} \mathrm{C}$ and $33{ }^{\circ} \mathrm{C}$ with $39-40{ }^{\circ} \mathrm{C}$ high and thresholds of $8^{\circ}-12^{\circ} \mathrm{C}$.

Cinzana vegetation is dominated by tree strata, shrubs and grasses.

Kouyate et al., (2014) and Kablan et al., (2008) reported that soil of the area is classified as a leached tropical ferruginous soil with spots and concretions and Alfisols according to Soil Taxonomy (SoilSurvey Staff, 1999), with many Paleustalfs and frequent Plinthustalfs. The Ustalf classification indicates that the soils are, indeed, highly weathered and highly leached. The classification of Plinthustalfs is of special concern because it indicates that the soils contain a plinthite layer of soft $\mathrm{Fe}$ and $\mathrm{Al}$ oxides that will harden irreversibly into lateritic stone if exposed. 
International Journal of Agriculture and Environmental Research

ISSN: 2455-6939

Volume: 07, Issue: 06 "November-December 2021"
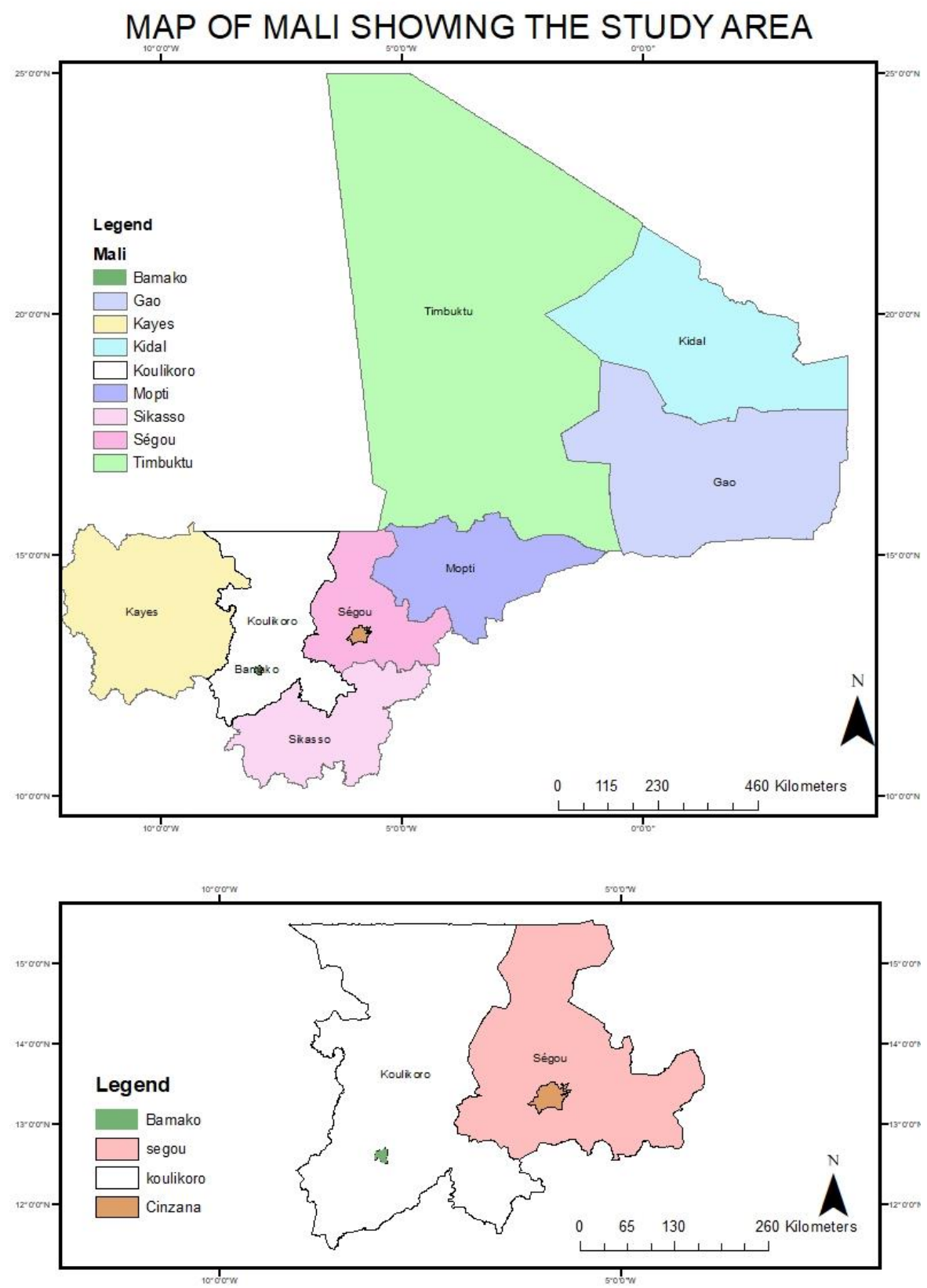

Figure 1: Map showing the study area

\section{Vegetal material}

Two sorghum genotypes and a cowpea genotype were chosen to conduct an experiment field in 2017 and 2018. Their characteristics are described in the table 1. 
International Journal of Agriculture and Environmental Research

ISSN: 2455-6939

Volume: 07, Issue: 06 "November-December 2021"

Table 1: sorghum and cowpea genotypes characteristics

\begin{tabular}{|c|c|c|c|c|c|c|}
\hline Crop & Name & $\begin{array}{l}\text { Adaptation } \\
\text { zone }\end{array}$ & $\begin{array}{l}\text { Cycle } \\
\text { (days) }\end{array}$ & $\begin{array}{l}\text { Rainfall } \\
\text { isohyet } \\
(\mathbf{m m})\end{array}$ & $\begin{array}{l}\text { Plant } \\
\text { height } \\
\text { (m) }\end{array}$ & $\begin{array}{l}\text { potential Yield } \\
\left(\text { t.ha }{ }^{-1}\right)\end{array}$ \\
\hline \multirow[t]{2}{*}{ Sorghum } & $\begin{array}{l}\text { Jacumbe (CSM } \\
\text { 63E) }\end{array}$ & Sahelian & 1000 & $400-700$ & 2.10 & Grain: 2 \\
\hline & $\begin{array}{l}\text { Tiandougou- } \\
\text { coura (04-SB- } \\
\text { F5-Dt-105) }\end{array}$ & Soudanian & 120 & $800-1000$ & 1.8 & Grain: $2.5-3$ \\
\hline \begin{tabular}{|l} 
Cowpea \\
\end{tabular} & Korobalen & Sahelian & $60-65$ & $300-800$ & - & $\begin{array}{l}\text { Grain: 1-1.5 } \\
\text { Fodder: low }\end{array}$ \\
\hline
\end{tabular}

\section{Experimental design}

Field trial were conducted in 2017 and 2018 at two different sowing date.

The experiments were laid out as three factorials in which the factor sowing date as fixed factor and the factors "sorghum varieties" and "row arrangement of intercropping system" as random factors in split-plot with three (3) replications.

Two varieties of sorghum (long cycle: TiandougouCoura (Tiand), short cycle: Jacumbe (Jac)), one variety of cowpea (Korobalen (Kor)) under monoculture and intercropping systems with four different row arrangements $(2: 2,2: 1,1: 2,1: 1)$; which make eleven (11) treatments in each replication and thirty-three 33 for the three replications (table2).

Table 2: Treatments of the trial

\begin{tabular}{|l|l|}
\hline Genotypes and Row arrangement & Code \\
\hline 2Tiandougou coura:2 korobalen & 2Tiand:2Kor \\
\hline 1Tiandougou coura:2 korobalen & 1Tiand:2Kor \\
\hline 2Tiandougou coura:1 korobalen & 2Tiand:1Kor \\
\hline 1Tiandougou coura:1 korobalen & 1Tiand:1Kor \\
\hline Tiandougoucoura pure & TiandP \\
\hline
\end{tabular}


International Journal of Agriculture and Environmental Research

ISSN: 2455-6939

Volume: 07, Issue: 06 "November-December 2021"

\begin{tabular}{|l|l|}
\hline 2Jacumbe:2 korobalen & 2Jac:2Kor \\
\hline 1Jacumbe:2 korobalen & 1 Jac:2Kor \\
\hline 2Jacumbe:1 korobalen & 2Jac:1 Kor \\
\hline 1Jacumbe:1 korobalen & 1Jac:1 Kor \\
\hline Jacumbe pure & JacP \\
\hline Korobalen pure & KorP \\
\hline
\end{tabular}

The land was prepared by disc plough, leveled and ridged. The spacings between ridges and holes were $75 \mathrm{~cm}$ and $30 \mathrm{~cm}$ respectively. The size of the plot was $6 \times 5 \mathrm{~m}^{2}$, consisting of eight ridges of $6 \mathrm{~m}$ length. Crops were sown on the second week of July for the first sowing date while second sowing was done on the fourth week of the July.

The seed rate was 4 seeds per hole. Fifteen days after weeds planting were manually cleaned and the holes thinning to two plants per hole.

DAP was applied at a rate of $100 \mathrm{~kg} / \mathrm{ha}$ after thinning. Forty-five days after planting second weeding was done and Urea $(46 \% \mathrm{~N})$ was applied at a rate of $50 \mathrm{~kg} \mathrm{~N} / \mathrm{ha}$ on one side of the ridge on both crops. Cowpea was sprayed with K_optimal against white fly, while sorghum was sprayed with Furadan against stem borer.

\section{Climate data collection}

\section{Soil data}

Initial soil sampling was taking in a zigzag manner across the field using a soil auger at $0-10,20-$ $30,30-60,60-90 \mathrm{~cm}$ depths and composite into one sample per depth for physical and chemical analysis before application of treatments in 2017. Thereafter soil samples were collected at 0-10 $\mathrm{cm}$ and 10-30 $\mathrm{cm}$ depth for organic matter and nitrogen analysis respectively after harvesting of sorghum and cowpea from each treatment in 2018. The observed soil properties were used for soil characterization under intercropping.

\section{Crop data}

The parameters collected were:

For sorghum: sowing date, leaf number, plant height, stem diameter, leaf area index (LAI) and yield parameters (grain and biomass). 
For cowpea: sowing date, ramification number, stem diameter, yield parameters (grain and biomass).

\section{RESULT AND DISCUSSION}

\section{Experimental soil characteristics}

The results in the table 3 indicate that, experimental site is mainly sandy and loamy of low fertility. They are classified as Lixisol in the FAO classification. The type of soil occurs dominantly in the drier parts of the tropics and subtropics. Their high base status is partly due to less leaching, partly to admixture from airborne dust from adjacent desert regions. These types of soils are strongly weathered soils with low levels of available nutrients and low nutrient reserves. The percentage of clay is low which means low quantity of organic matter. Soils high in clay and silt are generally higher in SOM content than sandy soils. This is attributed to restricted aeration in finer-textured soils, reducing the rate of organic matter oxidation, and the binding of humus to clay particles, further protecting it from decomposition.

Table 3: Physical proprieties of the experimental site

\begin{tabular}{|c|c|c|c|c|}
\hline Trial & Depht & $\begin{array}{c}\text { Sand \% > } \\
0.05 \mathrm{~mm}\end{array}$ & $\begin{array}{c}\text { Limon } \\
\text { fin \% 0.05- } \\
0.002 \mathrm{~mm}\end{array}$ & $\begin{array}{l}\text { Clay } \%< \\
0.002 \mathrm{~mm}\end{array}$ \\
\hline \multirow{5}{*}{ 1st sowing } & $0-10$ & 70 & 24 & 6 \\
\hline & $10-30$ & 55 & 40 & 4 \\
\hline & $30-60$ & 70 & 26 & 4 \\
\hline & $0-10$ & 47 & 44 & 8 \\
\hline & $10-30$ & 31 & 67 & 2 \\
\hline 2nd sowing & $30-60$ & 36 & 60 & 4 \\
\hline
\end{tabular}

\section{Effect of changes in long term rainfall trends on soil fertility and sorghum yields}

The result presented in Figure 2 indicates that there is much variation of rainfall amount from 1975 to 2014.1977 is the year of the lowest amount of rainfall $(771.7 \mathrm{~mm})$ and the starting year of rainfall declined in within the period of the study (1970-2018) though the year 1970 were above the mean and recorded the highest amount of rainfall $(1006.8 \mathrm{~mm})$. Rain increased between 1974 and 1980 and decreased between 1981 and 1990 with the lowest amount of 
rainfall in $1985(522.8 \mathrm{~mm})$. The average rainfall was $700.30 \mathrm{~mm}$ with 132.95 and 5.26 of standard deviation and coefficient of variation respectively. The trend line indicates that the annual rain has slightly increased over the study period and $\mathrm{R}^{2}$ value equal to 0.0019 indicates that there is no significant increase in rainfall amount from 1970 to 2018.

The decrease in annual total rainfall is confirmed in most part of Africa (Frappartet al.,2009; Ozer et al., 2009; Hountondjiet al., 2011). Similar finding was observed of the overall reduction in rainfall in the studies over the Sahel (Biasutti, 2013; Mohamed, 2011; Ackerleyet al., 2011; Lebel and Ali, 2009; Nicholson et al., 2000). It was also found in the study done by New et al. (2006) non- significant, but in total rainfall positive trends from heavy events for the West Africa and Southern Africa region.

Cinzana experienced two successive dryness years from 1982 to 1990 and from 2002 to 2006. The period of 1974 and 1975 were normal wet while 1976 were mild wet years. Based on the criteria of metrological agency standardized precipitation index interpretation, the dryness year was 1986 while the wetness was 1970 with respective standardized value of -1.33 (moderate dryness) and +2.30 (extreme dryness). Rainfall variability for the coherent areas is constructed from rainfall anomaly indices (RAI), based on the coherent areas, and a rainfall typology taking into account the spatial pattern of the rainfall anomaly fields and the intensity of the anomaly (Moron, 1994).

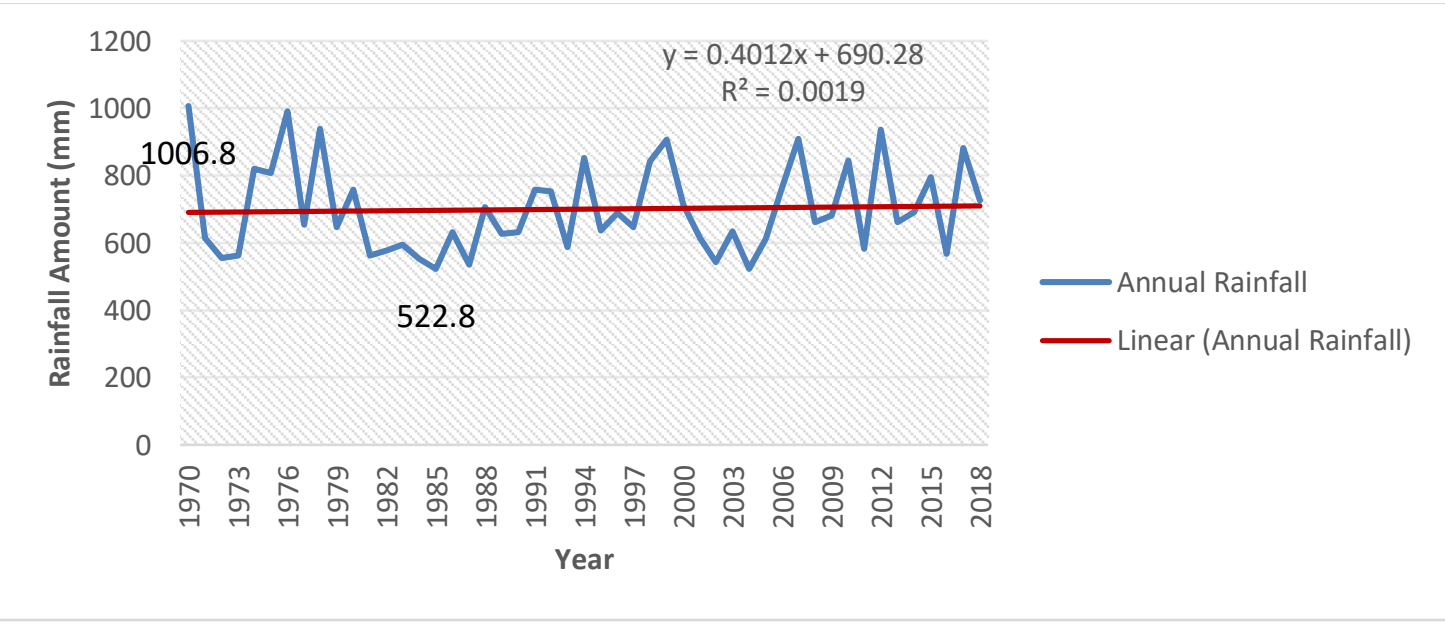

Figure 2: Annual Rainfall from 1970 to 2018

Intercropping and sowing date effects on sorghum and cowpea yields and growth parameters

Sorghum growth parameter in 2017 
Table 4 present the stem diameter, plant height, LAI, leaf Number, grain and biomass yields of sorghum under mono cropping and intercopping system in 2017. The results show that a slight variation in stem diameter, plant height and these are significatly affected only by genotype . We known that the leaf number and LAI were signifantly affected by sowing date and genotype while the grain yield are signicantly affected by cropping system and genotype. Altaught, the high variation in biomass yield we did not fund any difference signicative between sowing date, genotype and cropping system in 2017 season. The highest grain yield (2193 and $1842 \mathrm{~kg} / \mathrm{ha}$ ) and biomass yield (4570 and 4637) was recorded with one line sorghum jacumbe alternated with 1 line of cowpea korobalen (2Jac1Kor) in he two sowing date.

Table 4: Analyse of variance of sorghum growth parameter in 2017

\begin{tabular}{lllllll}
\hline Source of variation & d.f. & s.s. & m.s. & v.r. & l.s.d. & F pr. \\
\hline Sowing & 1 & 0.01873 & 0.01873 & 0.22 & 0.152 & 0.641 \\
Genotype & 1 & 0.89467 & 0.89467 & 10.58 & 0.152 & $0.002^{*}$ \\
Rowarr & 9 & 0.63506 & 0.07056 & 0.83 & 0.3398 & 0.589 \\
Sowing.Genotype & 1 & 0.00113 & 0.00113 & 0.01 & 0.2149 & 0.909 \\
Sowing.Rowarr & 9 & 0.8526 & 0.09473 & 1.12 & 0.4806 & 0.372 \\
Residual & 38 & 3.21262 & 0.08454 & & & \\
se & 0.2908 & & & & & \\
cv & 17.9 & & & & & \\
\end{tabular}

\begin{tabular}{lllllll}
\hline & \multicolumn{5}{c}{$\begin{array}{l}\text { Plant } \\
\text { Height }\end{array}$} \\
& 1 & 0.01103 & 0.01103 & 0.21 & 0.1207 & 0.652 \\
Sowing & 1 & 28.19005 & 28.19005 & 528.5 & 0.1207 & $<.001^{* *}$ \\
Genotype & 9 & 0.56017 & 0.06224 & 1.17 & 0.2699 & 0.343 \\
Rowarr & 1 & 0.08664 & 0.08664 & 1.62 & 0.1707 & 0.21 \\
Sowing.Genotype & 9 & 0.4223 & 0.04692 & 0.88 & 0.3817 & 0.551 \\
Sowing.Rowarr & 9 & 2.0269 & 0.05334 & & &
\end{tabular}


International Journal of Agriculture and Environmental Research

ISSN: 2455-6939

Volume: 07, Issue: 06 "November-December 2021"

\begin{tabular}{|c|c|c|c|c|c|c|}
\hline $\mathrm{Se}$ & 0.231 & & & & & \\
\hline $\mathrm{cv}$ & 9.8 & & & & & \\
\hline & & & LAI & & & \\
\hline Sowing & 1 & 0.008014 & 0.008014 & 14.21 & 0.01241 & $<.001^{* *}$ \\
\hline Genotype & 1 & 0.002695 & 0.002695 & 4.78 & 0.01241 & $0.035^{*}$ \\
\hline Rowarr & 9 & 0.006047 & 0.000672 & 1.19 & 0.02775 & 0.328 \\
\hline Sowing.Genotype & 1 & 0.000246 & 0.000246 & 0.44 & 0.01755 & 0.513 \\
\hline Sowing.Rowarr & 9 & 0.004447 & 0.000494 & 0.88 & 0.03925 & 0.554 \\
\hline Residual & 38 & 0.021428 & 0.000564 & & & \\
\hline $\mathrm{Se}$ & 0.02375 & & & & & \\
\hline $\mathrm{cv}$ & 30.1 & & & & & \\
\hline
\end{tabular}

\begin{tabular}{lllllll}
\hline \multicolumn{7}{c}{ Leaf Number } \\
\hline Sowing & 1 & 146.2241 & 146.2241 & 216.8 & 0.15 & $<.001^{* *}$ \\
Genotype & 1 & 148.313 & 148.313 & 219.9 & 0.15 & $<.001^{* *}$ \\
Rowarr & 9 & 3.837 & 0.4263 & 0.63 & 0.335 & 0.762 \\
Sowing.Genotype & 1 & 181.4241 & 181.4241 & 268.99 & 0.212 & $<.001^{* *}$ \\
Sowing.Rowarr & 9 & 2.3704 & 0.2634 & 0.39 & 0.474 & 0.932 \\
Residual & 38 & 25.6296 & 0.6745 & & & \\
\hline se & 0.821 & & & & & \\
\hline $\mathrm{cv}$ & 6.4 & & & & & \\
\hline
\end{tabular}

\section{Grain Yield}

$\begin{array}{lllllll}\text { Sowing } & 1 & 775712 & 775712 & 3.59 & 243 & 0.066 \\ \text { Genotype } & 1 & 4302296 & 4302296 & 19.9 & 243 & <.001^{* *}\end{array}$


International Journal of Agriculture and Environmental Research

ISSN: 2455-6939

Volume: 07, Issue: 06 "November-December 2021"

$\begin{array}{lllllll}\text { Rowarr } & 9 & 6832724 & 759192 & 3.51 & 543.4 & 0.003 * * \\ \text { Sowing.Genotype } & 1 & 387564 & 387564 & 1.79 & 343.7 & 0.189 \\ \text { Sowing.Rowarr } & 9 & 1383638 & 153738 & 0.71 & 768.5 & 0.695 \\ \text { Residual } & 38 & 8214979 & 216184 & & & \end{array}$

\begin{tabular}{ll}
\hline $\mathrm{Se}$ & 465 \\
\hline $\mathrm{cv}$ & 37.9 \\
\hline
\end{tabular}

\begin{tabular}{lllllll}
\hline & \multicolumn{7}{c}{$\begin{array}{l}\text { Biomass } \\
\text { Yield }\end{array}$} \\
\hline Sowing & 1 & 4238270 & 4238270 & 3.04 & 617.3 & 0.089 \\
Genotype & 1 & 1380841 & 1380841 & 0.99 & 617.3 & 0.326 \\
Rowarr & 9 & 24531178 & 2725686 & 1.95 & 1380.4 & 0.073 \\
Sowing.Genotype & 1 & 5421354 & 5421354 & 3.89 & 873 & $0.056^{*}$ \\
Sowing.Rowarr & 9 & 7591352 & 843484 & 0.6 & 1952.2 & 0.785 \\
Residual & 38 & 53005156 & 1394873 & & & \\
& & & & & & \\
\hline Se & 1181 & & & & \\
\hline cv & 36.8 & & & & \\
\hline
\end{tabular}

\section{Sorghum growth parameter under intercropping system in 2018}

Table 4 discovered that the stem diameter, plant height, LAI, Leaf number, grain and biomass yield were not affected by cropping system in 2018 rain season. Exclude the biomass yield, a significant difference was observed in all parameter according to sowing date. The Highest stem diameter value was obtained with $2 \mathrm{Jac} 2 \mathrm{Kor}$ and $2 \mathrm{Jac} 1$ Kor $(1.74 \mathrm{~cm})$ in second sowing while a highest plant height fund in the first sowing. The best grain yield was fund with 1Kor2Tiand in second sowing $(1377 \mathrm{~kg} / \mathrm{ha})$ and the best biomass yield $(2378 \mathrm{~kg} / \mathrm{ha})$ with $2 \mathrm{Kor} 1 \mathrm{Jac}$ in the first sowing. 
International Journal of Agriculture and Environmental Research

ISSN: 2455-6939

Volume: 07, Issue: 06 "November-December 2021"

Table 5: Analyse of variance of sorghum growth parameter in 2018

\begin{tabular}{|c|c|c|c|c|c|c|}
\hline & & & $\begin{array}{l}\text { Stem } \\
\text { Diameter }\end{array}$ & & & \\
\hline Source & & & & & & \\
\hline variation & d.f. & s.s. & m.s. & v.r. & 1.s.d. & F pr. \\
\hline Sowing & 1 & 2.5751 & 2.5751 & 11.93 & 0.243 & $0.001 * *$ \\
\hline Genotype & 1 & 0.7049 & 0.7049 & 3.26 & 0.243 & 0.079 \\
\hline Rowarr & 9 & 1.7652 & 0.1961 & 0.91 & 0.543 & 0.528 \\
\hline Sowing.Genotype & 1 & 0 & 0 & 0 & 0.343 & 0.993 \\
\hline Sowing.Rowarr & 9 & 0.5481 & 0.0609 & 0.28 & 0.768 & 0.976 \\
\hline Residual & 38 & 8.2041 & 0.2159 & & & \\
\hline $\mathrm{Se}$ & 0.465 & & & & & \\
\hline $\mathrm{CV}$ & 37.9 & & & & & \\
\hline & & & Plant Heig & & & \\
\hline Sowing & 1 & 1.8821 & 1.8821 & 17.75 & 0.17 & $<.001 * *$ \\
\hline Genotype & 1 & 8.2337 & 8.2337 & 77.64 & 0.17 & $<.001 * *$ \\
\hline Rowarr & 9 & 0.9457 & 0.1051 & 0.99 & 0.381 & 0.464 \\
\hline Sowing.Genotype & 1 & 0.6573 & 0.6573 & 6.2 & 0.241 & $0.017 * *$ \\
\hline Sowing.Rowarr & 9 & 0.3956 & 0.044 & 0.41 & 0.538 & 0.919 \\
\hline Residual & 38 & 4.03 & 0.1061 & & & \\
\hline $\mathrm{Se}$ & 0.326 & & & & & \\
\hline $\mathrm{CV}$ & 16.3 & & & & & \\
\hline & & & LAI & & & \\
\hline Sowing & 1 & 0.090356 & 0.090356 & 21.36 & 0.034 & $<.001 * *$ \\
\hline Genotype & 1 & 0.004772 & 0.004772 & 1.13 & 0.034 & 0.295 \\
\hline er.in & Cop & t @ ( IJAER 2 & 21, All rights 1 & reserved & & Page 1069 \\
\hline
\end{tabular}


International Journal of Agriculture and Environmental Research

ISSN: 2455-6939

Volume: 07, Issue: 06 "November-December 2021"

$\begin{array}{lllllll}\text { Rowarr } & 9 & 0.038001 & 0.004222 & 1 & 0.076 & 0.458 \\ \text { Sowing.Genotype } & 1 & 0.00046 & 0.00046 & 0.11 & 0.048 & 0.743 \\ \text { Sowing.Rowarr } & 9 & 0.043457 & 0.004829 & 1.14 & 0.108 & 0.359 \\ \text { Residual } & 38 & 0.160761 & 0.004231 & & & \\ \text { Se } & 0.065 & & & & & \\ \text { CV } & 37.4 & & & & & \end{array}$

Leaf Number

\begin{tabular}{lllllll} 
Sowing & 1 & 0.704 & 0.704 & 0.1 & 1.4 & 0.759 \\
Genotype & 1 & 1.504 & 1.504 & 0.2 & 1.4 & 0.654 \\
Rowarr & 9 & 53.33 & 5.926 & 0.81 & 3.2 & 0.614 \\
Sowing.Genotype & 1 & 9.204 & 9.204 & 1.25 & 2 & 0.27 \\
Sowing.Rowarr & 9 & 83.856 & 9.317 & 1.27 & 4.5 & 0.287 \\
Residual & 38 & 279.648 & 7.359 & & & \\
Se & 2.7 & & & & & \\
CV & 26.3 & & & & & \\
\hline & & & Grain Yield & & \\
\hline Sowing & 1 & 1047788 & 1047788 & 4.44 & 253.9 & $0.042^{*}$ \\
Genotype & 1 & 808598 & 808598 & 3.43 & 253.9 & 0.072 \\
Rowarr & 9 & 1819918 & 202213 & 0.86 & 567.6 & 0.57 \\
Sowing.Genotype & 1 & 500831 & 500831 & 2.12 & 359 & 0.153 \\
Sowing.Rowarr & 9 & 831974 & 92442 & 0.39 & 802.8 & 0.931 \\
Residual & 38 & 8962873 & 235865 & & & \\
Se & 392.6121 & & & & & \\
CV & 31 & & & & & \\
& & & & & & \\
& & & & & & \\
\end{tabular}


International Journal of Agriculture and Environmental Research

ISSN: $2455-6939$

Volume: 07, Issue: 06 "November-December 2021"

\begin{tabular}{lllllll}
\hline & \multicolumn{7}{c}{ Biomass Yield } \\
\hline Sowing & 1 & 3807900 & 3807900 & 3.76 & 526 & 0.06 \\
Genotype & 1 & 18812 & 18812 & 0.02 & 526 & 0.892 \\
Rowarr & 9 & 12571204 & 1396800 & 1.38 & 1176.2 & 0.232 \\
Sowing.Genotype & 1 & 5424147 & 5424147 & 5.36 & 743.9 & $0.026^{*}$ \\
Sowing.Rowarr & 9 & 5275034 & 586115 & 0.58 & 1663.3 & 0.806 \\
Residual & 38 & 38480805 & 1012653 & & & \\
Se & 1006.3 & & & & & \\
CV & 50.5 & & & & &
\end{tabular}

\section{Land Equivalent Ratio (LER) of sorghum and Cowpea under intercropping system}

LER values above 1.0 were obtained for all intercropping treatments (table 5). This indicates that a higher total yield can be obtained from sorghum-legume intercropping than from sole sorghum or sole cowpea. The present and previous studies clearly indicate the higher productive efficiency of intercropping. Generally, relative yields (RY) of legumes were lower than that of sorghum, which confirms previous finding that in legume/non-legume mixtures the yield of legumes were more depressed than yield of non-legumes (Nyambo et al., 1980).

Ali at al., (2015) found that, maize-soybean intercropping increased soil organic carbon content, CEC, N, Ca, Mg and P level after harvesting than sole crops. Wang et al., (2014) reported that, globally, soil organic matter did not differ significantly from monocropping but did increase in maize-chickpea intercropping in two years. Intercropping reduced significantly soil cation exchangeable capacity (CEC) and soil p H. In the majority of cases soil enzyme activities did not differ across all the cropping systems at different $\mathrm{P}$ application rates compared to monocrops. Regehr (2014) reported that, soil quality improved significantily in maize-soybean intercropping than monocropping system. Intercropping resulted in higher rates of gross $\mathrm{N}$ mineralization than the sole crops, and the 2:3 intecrop resulted in higher rates of gross $\mathrm{N}$ immobilization than other treatments.

It has been long known that many intercropping systems used in the world by farmers have a land equivalent ratio above one (Lithourgidis et al., 2011). A land equivalent ratio greater than one does not necessarily mean that in any 1 year, an intercrop would produce more biomass than both of the sole crops (i.e. transgressive overyielding) (Trenbath, 1974). Still, if a farm plan or 
rotation with (mostly) intercrops were compared to a farm plan or rotation with mostly sole crops, then land use systems with a greater proportion

of intercrops (provided LER > 1) are expected to produce more biomass on the whole. When averaged out over fields on the farm or for a single field over time, an LER greater than 1 would result in overall greater biomass or yield, and in the case of soil carbon balance: greater $\mathrm{C}$ input.

Table 6: LER of sorghum intercrop with cowpea in 2017 and 2018

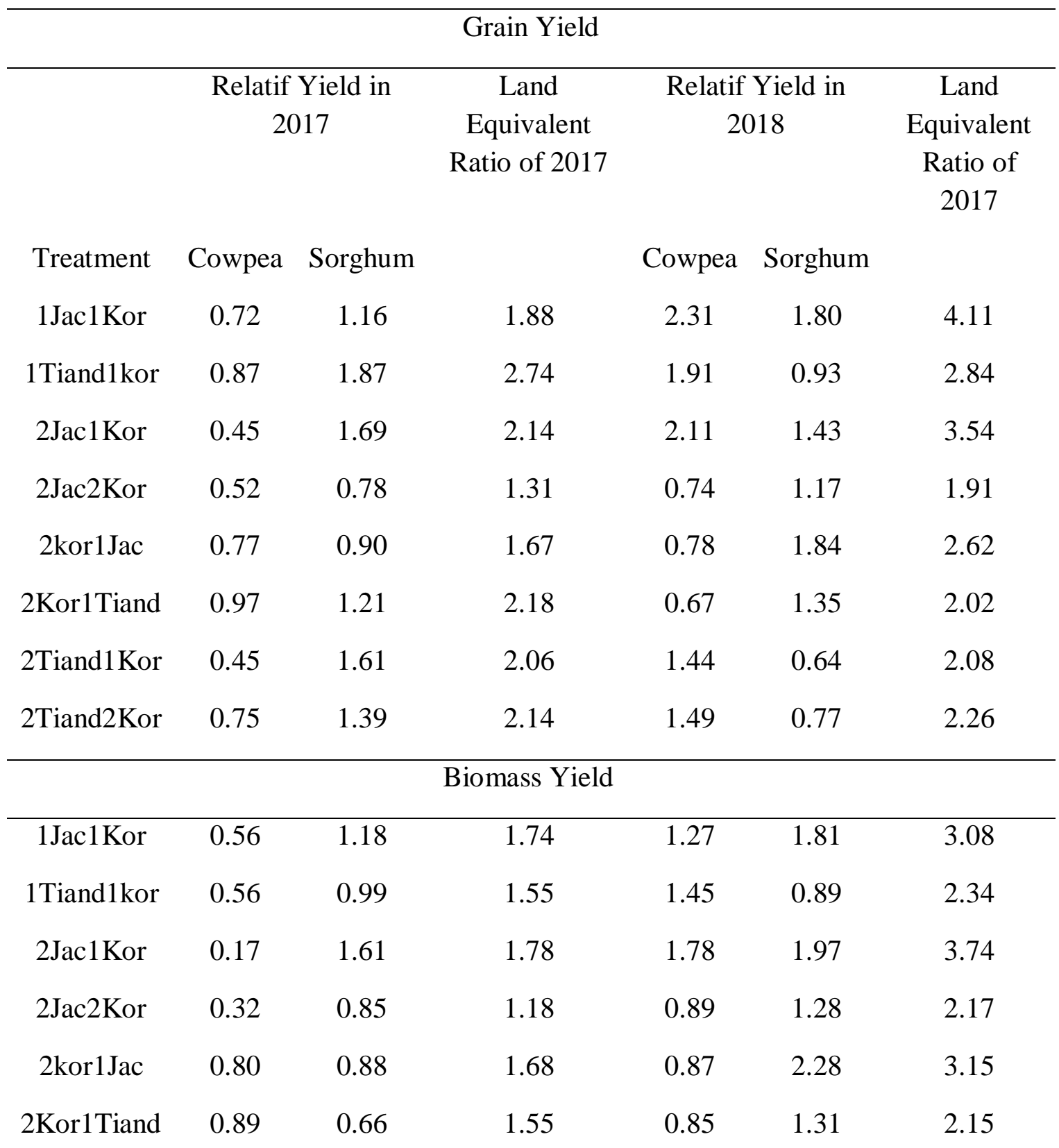


International Journal of Agriculture and Environmental Research

ISSN: 2455-6939

Volume: 07, Issue: 06 "November-December 2021"

$\begin{array}{lllllll}\text { 2Tiand1Kor } & 0.42 & 0.90 & 1.32 & 1.16 & 0.81 & 1.97 \\ \text { 2Tiand2Kor } & 0.63 & 0.98 & 1.62 & 1.51 & 1.00 & 2.51\end{array}$

\section{CONCLUSION}

A study on the effect of intercropping on the improvement of sorghum yield under high variability rain-fed conditions was undertaken for two consecutive years. The aim was to evaluate the effects of intercropping on the characteristics of soil and sorghum yield under climate variability. The data indicated that the association of legumes in different row arrangement with sorghum affected the yield and biomass of sorghum. During both the years of study, planting pattern significantly increased the grain yield of sorghum, as compared with monoculture. The results reveal that intercropping was more efficient productive system than sole cropping as reflected by the high LER values. Generally, sorghum showed better performance when intercropping with cowpea.

There for acceding to the results of this study, there for acceding to the results of this study, Jacumbe can recommend as a suitable sorghum variety intercrop with cowpea in Cinzana (Sahelian zone). Sorghum showed better performance when intercropping with cowpea depending on the variety and season. The sowing date and rain season has significant effect on sorghum and cowpea yield under intercropping system.

\section{RECOMMENDATION}

Further studies are needed in order to fully evaluate the potential of intercropping with respect to its influence on aspects such as crop yield as well as other aspects such as soil structure, soil fertility and weed infestation. More information is also needed on optimum crop densities, crop ratios and suitable crop mixtures.

\section{REFERENCES}

[1] Breman, H. and Sissoko, K. (1998). L'intensification Agricole au Sahel. Paris, Karthala Editions Pp 996.

[2] Butt T.A., Mccarl B.A., Angerer J., Dyke P.T., and Stuth J.W. (2005). The Economic and Food Security Implications of Climate Change in Mali. Climatic Change 68:355-378.

[3] DNS. (Enquête Agricole De Conjoncture). (1995). 1994-1995 Résultats Définitifs, Bamako. DNA, Août 1995, 52p.

[4] Drechsel, P., Gyiele, L., Kunze, D. and Cofie, O. (2001). Population Density, Soil Nutrient Depletion, and Economic Growth in Sub-Saharan Africa. Ecological Economics, 38(2): 251-258. 
International Journal of Agriculture and Environmental Research

ISSN: 2455-6939

Volume: 07, Issue: 06 "November-December 2021"

[5] IPCC. (2013). Summary for Policymakers. In: T.F. Stocker Et Al. (Editors), Climate Change 2013: The Physical Science Basis. Contribution of Working Group I to The Fifth Assessment Report Chuku, C.A. and Okoye, C. (2009). Increasing resilience reducing vulnerability in sub-Saharan African agriculture: strategies for risk coping and management. African Journal of Agricultural Research 4: 1524-1535.

[6] Kablan R., Yost R. S., Brannan K., .Doumbia M. D., Traoré K., Yoroté A., Toloba Y., Sissoko S., Samaké O., Vaksman M., Dioni L. and Sissoko M. (2008). "Aménagementencourbes de niveau." Increasing Rainfall Capture, Storage, and Drainage in Soils of Mali. Arid Land Research and Management, 22:1, 62-80.

[7] Kouyaté Z., Krasova-Wade T., Yattara I.I. and Neyra M. (2014). Effects of cropping system and Cowpea variety (Vigna unguiculata L. Walp) on the diversity of native cowpea bradyrhizobia and millet yield in the Sudano Sahelian zone of Mali. Int. Res. Journal of Agriculture Science and Soil Science, 4 (2): 30-39

[8] Lithourgidis A, Vlachostergios D, Dordas C, Damalas C. Dry matter yield, nitrogen content, and competition in pea-cereal intercropping systems. European Journal of agronomy. 2011;34:287-294. doi: 10.1016/j.eja.2011.02.007.

[9] Muller, C., Bondeau, A., Popp, A., Waha, K. and Fader, M. (2010). Climate change impacts on agricultural yields. Background note to the World Development Report 2010. Potsdam Institute for Climate Impact Research, Potsdam.

[10] Oxfam. (2007). Understanding gender differential impacts of tsunami and gender mainstreaming strategies in tsunami response in Tamil Nadu, India. no city

[11] Schwartz, P. and Randall, D. (2003). An Abrupt Climate Change Scenario and Its Implications for United States National Security. Accessed On 20 July 2009. Http://Www.Greenpeace.Org/Raw/Content/International/Press/Reports/An-AbruptClimate-Changescena. Pdf.

[12] Soil Survey Staff 1999, Soil Taxonomy. A basic system of soil classification for making and interpreting soil surveys, 2nd edition.

[13] Sultan, B. and Janicot, S. (2003). The West African Monsoon Dynamics. Part II: The "Preonset" and "Onset" of the Summer Monsoon. Journal of Climate 16: 3407-3427.

[14] Traore, B., van Wijk, M. T., Descheemaeker, K., Corbeels, M., Rufino, M. C. and Giller, K. E. (2014). Evaluation of climate adaptation options for Sudano-Sahelian cropping systems. Field Crops Research 156:63-75.

[15] Vandermeer, J. H. The ecology of intercropping. (Cambridge University Press 1992)

[16] Wang, Q., Jacob, D. J., Spackman, J. R., Perring, A. E., Schwarz, J. P., Moteki, N., . . Barrett, S. R. H. (2014). Global budget and radiative forcing of black carbon aerosol: Constraints from pole-to-pole (HIPPO) observations across the Pacific. 119(1), Journal of Geophysical Research195-206. doi:10.1002/2013JD020824 